\title{
PEMANFAATAN SITUS JEJARING SOSIAL SEBAGAI MEDIA BELAJAR DENGAN CARA UPDATE CHAPTER
}

\author{
Evi Mahsunah \\ Universitas Nahdlatul Ulama Sidoarjo \\ evimahsunahtaman@yahoo.com \\ Wahyu Maulida Lestari \\ Universitas Nahdlatul Ulama Sidoarjo \\ wahyu.maulida290990@gmail.com
}

\begin{abstract}
Abstrak
Kepraktisan dan beragam fasilitas yang ditawarkan oleh situs jejaring sosial pada masa disrupsi ini harus dapat dimanfaatkan dalam pembelajaran. Oleh karena itu penelitian ini bertujuan untuk memanfaatkan situs jejaring sosial sebagai media pembelajaran dengan caramerubah kebiasaan mahasiswa update status menjadi update chapter dan mengetahui respon mahasiswa terhadap penggunaan sistem update chapter. Penelitian ini menggunakan pendekatan deskriptif-kualitatif, pengumpulan data menggunakan teknik observasi, wawancara dan kuesioner. Penelitian ini memperoleh data bahwa sebagian besar mahasiswa sangat aktif membuka dan membaca group update chapter mereka setiap saat ada teman yang meng-update chapter atau memberi komentar. Kemudian, mereka juga sering menuliskan update chapter atas apa yang telah mereka baca dan pelajari dari bukubuku referensi perkuliahannya. Mereka tidak mau meng-update chapter asal-asalan tanpa landasan teori karena hal itu akan menjadikan update mereka tidak menarik dan tidak mendapatkan poin nilai tinggi. Hasil penelitian ini diharapkan mampu berkontribusi dalam merubah fenomena update status menjadi lebih bermanfaat dengan caraupdate chapter di situs jejaring sosial.
\end{abstract}

Kata kunci: situs jejaring sosial, media pembelajaran, update chapter

\section{PENDAHULUAN}

Perkembangan teknologi dan informasi di era disrupsi membawa dampak besar di dunia pendidikan. Situs jejaring sosial mempunyai peran yang sangat penting dan telah menjadi bagian yang tidak bisa terpisahkan dari kehidupan masyarakat. Kepraktisan dan beragam fasilitas yang ditawarkan menjadi daya tarik yang memikat orangorang untuk terus menggunakannya, karena bisa berfungsi sebagai sarana komunikasi yang murah, cepat, dan mudah. Fenomena serupa juga terjadi di lingkungan Universitas NU Sidoarjo, situs jejaring sosial sudah menjadi bagian dari kehidupan sehari-hari mahasiswa. Setiap hari kita bisa melihat di kampus para mahasiswa selalu aktif menggunakan media sosial. Setiap saat mereka membuka beberapa media sosial seperti Facebook, BBM, Whatsapp, dan Twitter untuk mengupdate status atau hanya sekadar membaca status berita 
yang ditulis teman mereka. Hal tersebut juga dikemukakan oleh Arsyad (2013:195), menurutnya kini sudah hadir media sosial, dimana kita dapat mengetahui status orang-orang di seluruh dunia secara real time. Kehadiran berbagai macam media situs jejaring sosialdi dalam internet seperti Facebook, merupakan media situs jejaring sosialyang digunakanuntuk mempublikasikan konten, seperti profil, aktivitas, dan pendapat pengguna serta sebagai media yang memberikan ruang bagi komunikasi dan interaksi dalam jejaring sosial (Nasrullah,2015:40). Media situs jejaring sosial seperti Facebook, Twitter, dan lainnya tentu dapat membantu mahasiswa dalam mencari berbagai relasi dan informasi sesuai yang diinginkan.

Jejaring sosial (Social networking) menjadi fenomena yang cukup menarik untuk diteliti, karena dengan seiiring perkembangannya segala macam aktivitas dan kegiatan dapat diterapkan, salah satunya sebagai media pendidikan. Sebagai wadah komunikasi dan sumber informasi yang mudah diakses,media internet memfasilitasi dengan salah satunya adalah situs jejaring sosial. Boyd dan Ellison (2007) mendefinisikan situs situs jejaring sosial sebagai suatu layanan web yang membantu seseorang untuk melakukan tiga hal di dunia maya,yaitu membangun profil publik atau semipublik di dalam sebuah sistem yang terbatas, melihat "teman dari teman" yang ada dalam satu koneksi mereka, serta melihat dan melacak daftar teman, yang dibuat oleh mereka sendiri atau oleh orang lain, dalam satu jaringan. Situs-situs jejaring sosial dimanfaatkan oleh penggunanya tidak hanya untuk berkomunikasi saja. Akan tetapi lebih dari itu, situs-situs jejaring sosial juga digunakanuntuk berbagi informasi, mengisi waktu luang, atau bahkan melakukan bisnis (Sopiah, 2013).

Melihat fenomena berkembangnya situs jejaring sosial di kalangan mahasiswa, beberapa universitas mencoba untuk memanfaatkannya dengan menggunakan situs-situs jejaring sosial untuk media pembelajaran di kelas. Menurut Kirkwood \& Price (2014), sebuah teknologi yang digunakan dalam kegiatan belajar mengajar (technologyenhancedlearning) dapat memiliki tiga karakteristik, yaitu: (1) mereplikasi aktivitas pembelajaran yang sudah ada, (2) menjadi pelengkap aktivitas pembelajaran yang sudah ada, dan (3) mentransformasi proses dan hasil aktivitas belajar mengajar. Jika situssitus jejaring sosial digunakan sebagai media pembelajaran, maka fungsinya berubah atau diubah agar memiliki ketiga karakteristik tersebut (Silius, etal., 2010). Penggunaan situs-situs jejaring sosial di kelas bisa disebut dengan social media enhanced learning.

Berdasarkan fenomena ini, maka seorang pendidik harus mampu 
memanfaatkan situs jejaring sosial untuk menunjang kegiatan belajarmengajarnya, karena situs jejaring sosialdapat digunakan untuk sarana atau media pembelajaran. Dalam metodologi pengajaran, media merupakan salah satu aspek yang paling penting untuk mempertinggi proses belajar siswa yang pada gilirannya dapat mempertinggi hasil belajar yang dicapainya. Daryanto (2012:6) menyatakan bahwa "proses pembelajaran merupakan proses komunikasi dan berlangsung dalam suatu sistem maka media pembelajaran menempati posisi penting sebagai salah satu komponen sistem pembelajaran". Tanpa media pembelajaran, komunikasi tidak akan terjadi dan proses pembelajaran sebagai proses komunikasi juga tidak akan bisa berlangsung secara optimal. Pemakaian media pembelajaran juga dapat menunjang kegiatan belajar mengajar. Pada kenyataannya saat ini belum tampak penggunaan media situs jejaring sosialsecara maksimal, saat ini kebanyakan hanya digunakan oleh mahasiswa untuk sebatas berinteraksi atau chatting sesama teman, game, dan membeli barang secara online.

Beberapa penelitian sudah dilakukan untuk membuktikan manfaat situs jejaring sosial dalam dunia pendidikan. Salah satunya penelitian Hamzah (2016), yang berjudul “Tingkat Penerimaan Mahasiswa terhadap Penggunaan Situs Jejaring Sosial sebagai
Media Pembelajaran" menyimpulkan bahwa penggunaan situs jejaring sosial sebagai media pembelajaran bertujuan untuk mempermudah dan membantu aktivitas belajar mengajar dan komunikasi antara dosen dan mahasiswa. Sebagian besar mahasiswa memang menerima dan setuju dengan cara baru ini. Alasan yang mereka kemukakan adalah situs jejaring sosial mempermudah, membantu dalam kegiatan pembelajaran. Selain itu, penggunaan situs jejaring sosial sebagai media pembelajaran juga dinilai efektif dan efisien. Akan tetapi, di antara mahasiswa tersebut ada beberapa yang menganggap bahwa pemanfaatan situs jejaring sosial sebagai media pembelajaran justru akan mengurangi efektivitas dari proses pembelajaran.

Berdasarkan permasalahan di atas, penulis tertarik untuk melakukan penelitian tentang bagaimana memanfaatkan situs jejaring sosial sebagai media pembelajaran dengan cara update chapter dan bagaimana respon mahasiswa terhadap pemanfaatan situs jejaring sosial sebagai media pembelajaran dengan cara update chapter tersebut.

Update chapter merupakan istilah yang peneliti munculkan yang artinya adalah memperbarui bab atau unit buku yang kita baca. Hal ini untuk menggambarkan cara mengubah kebiasaan mahasiswa mengupdate status mereka di situs jejaring sosial 
menjadi Update chapter atau memperbarui bab. Update chapter merupkan sebuah strategi pembelajaran yang mewajibkan mahasiswa untuk aktif membaca buku-buku literatur mereka dan kemudian mendiskusikannya dengan cara mengupdate chapter atau bab dan membagi hasil bacaaannya di jejaring sosial. Jadi, mahasiswa selain mengupdate bacaannya juga harus aktif memberi komentar atau tanggapan atas update teman-temannya. Dengan cara ini, maka tidak hanya akan diketahui seberapa sering mahasiswa aktif membaca buku literaturnya, tetapi juga akan dapat diketahui bagaimana pemahaman mereka terhadap pembelajaran. Hal ini bisa dilihat dari cara mereka mengomentari update teman-temannya.

\section{METODE PENELITIAN}

Lokasi penelitian ini adalah jurusan Pendidikan Bahasa Inggris dan PGSD Fakultas Keguruan dan Ilmu Pendidikan Universitas NU Sidoarjo.Penelitian ini menggunakan pendekatan deskriptifkualitatif. Pengumpulan data pada Penelitian ini diambil melalui tiga tahap.Pertama observasi; observasi dilakukan sejak sebelum penggunaan update chapter hingga akhir penelitian.Tujuannya untuk mengamati aktifitas penggunaan situs jejaring sosial mahasiswa dan dosen di dalam kelas maupun diluar kelas. Kemudian wawancara yang dilakukan pada dosen pengampu mata kuliah Sociolinguistics dan Bahasa Daerah untuk memperoleh data bagaimana memanfaatkan situs jejaring sosial sebagai media pembelajaran dengan caraupdate chapter. Selanjutnya pemberian kuisioner atau angket: Kuisioner diberikan kepada mahasiswa untuk mengetahui respon mahasiswa terhadap pemanfaatan situs jejaring sosial sebagai media pembelajaran dengan caraupdate chapter.

Alur kegiatan penelitian ini ada lima tahapan, pertama studi pustaka dengan membaca berbagai sumber baik media cetak maupun online atau daring. Tahapan kedua yaitu mengadakan pelatihan kepada mahasiswa untuk sosialisasi penggunaan situs jejaring sosial sebagai media pembelajaran dengan caraupdate chapter. Tahap selanjutnya pemberian kuisioner, pemberian kuisioner dilakukan sebanyak dua kali, yaitu saat sebelum tindakan update chapter dan yang kedua saat sudah selesai pembelajaran menggunakan update chapter. Setiap responden diberikan pertanyaan tentang tanggapan mereka terhadap penggunaan situs jejaring sosial sebagai media pembelajaran dengan cara update chapter. Dari pertanyaan tersebut, responden memberikan jawaban berupa memilih jawaban yang sesuai dengan pendapatnya. Penelitian ini melibatkan 50 mahasiswa yang bersedia menjadi responden. Responden ini rata-rata berada di 
tahun kedua atau ketiga dari kuliahnya.

\section{HASIL DAN PEMBAHASAN}

Pemanfaatan Situs Jejaring Sosial

\section{dengan Cara Update Chapter}

Penelitian ini memanfaatkan situs jejaring sosial WhatsApp dan facebook saja sebagai media pembelajaran dengan caraupdate chapter karena berdasarkan hasil kuisioner awal semua mahasiswa mempunyai kedua akun tersebut. Dosen dan juga sekaligus sebagai peneliti dalam penelitian ini mengungkapkan bahwa update chapter dapat mengubah kebiasaan mahasiswa update status, sehingga banyak mahasiswa yang tertarik untuk menggunakan situs jejaring sosial sebagai media pembelajaran. Penggunaan situs jejaring sosial sebagai media pembelajaran bertujuan untuk mempermudah dan membantu aktivitas belajar mengajar dan komunikasi antara dosen dan mahasiswa. Sebagian besar mahasiswamemang menerima dan setuju dengan cara baru ini.

Berdasarkan data perolehan kuisioner pertama yang diberikan sebelum tindakan dapat diketahui bahwa Responden mempunyai akun di situs jejaring sosial untuk beberapa tujuan, namun tujuan utama penggunaan situs jejaring sosial menurut mereka adalah 100\% menyebutkan sebagai alat komunikasi dengan teman dan kerabat, 24\%

responden menjawab sebagai media belajar yang menunjang pembelajaran, $100 \%$ menjawab sebagai media untuk mendapatkan hiburan. 30\% responden yang menyebutkan bahwa mereka menggunakan situs jejaring sosial untuk mempromosikan atau branding barang.Selain itu, data yang diperoleh dari kuisioner juga mengungkapkan bahwa 37\% responden mengaku aktif menggunakan situs jejaring sosial lebih dari 90 menit dalam sehari. Mereka menghabiskan waktunya untuk membaca dan memberi komentar atas update status teman-teman mereka, dan tidak lupa meng update status mereka.

Adanya kegiatan update chapter di situs jejaring sosial mampu merubah pendapat mahasiswa dalam memanfaatkan situs jejaring sosial. Sejumlah 45 responden atau 90\% menjadi percaya dan setuju bahwa situs jejaring sosial dapat digunakan sebagai media pembelajaran. Kalau sebelumnya situs jejaring sosial hanya banyak digunakan untuk sarana memperbarui gambar atau mengungkapkan perasaan terhadap kondisi sekitar, maka dengan sistem update status mereka akan beralih mengupdate atau memperbarui status mereka dengan memposting teoriteori dari buku literature perkuliahan yang telah dibacanya, sehingga mereka akan terpacu untuk lebih banyak membaca buku literatur perkuliahan. Perbandingan penggunaan situs jejaring 
sosial sebelum dan sesudah tindakan

dapat dilihat pada gambar 1 :

\section{PENGGUNAAN SITUS JEJARING SOSIAL}

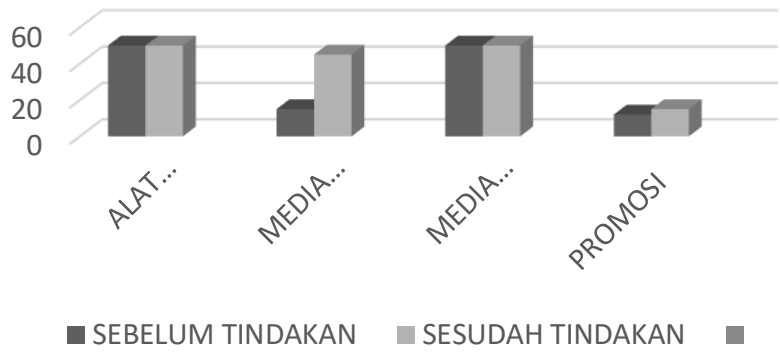

Gambar 1 Data penggunaan situs jejaring sosial pra dan sesudah tindakan

Berdasarkan wawancara dosen pengampu matakuliah Sociolinguistics dan Bahasa Daerah di FKIP UNUSIDA kegiatan ini ada beberapa tahap diantaranya: pertama, pelatihan penggunaan situs jejaring sosial sebagai media pembelajaran, disini pembicara menjelaskan kepada responden manfaat dan mudahnya belajar melalui situs jejaring sosial. Selain itu, pelatih juga membimbing mahasiswa cara-cara mengupdate chapter dan memberi komentar atas update temannya. Kedua, membuat group belajar "update your chapter" di situs jejaring sosial facebook dan WhatsApp. Kemudian menyajikan informasi-informasi terkait tugas perkuliahan ataupun topik yang akan dibahas di perkuliahan yang akan datang, memotivasi mahasiswa dan memantau mereka untuk aktif update chapter dan memberi komentar, memberi feedback atau masukan atas komentar ataupun update mereka, dan terakhir memberi reward berupa poin nilai bagi yang aktif.

\section{Respon Mahasiswa terhadap Penggunaan Sistem "Update Your Chapter"}

Mayoritas responden menyatakan sangat setuju dan senang dengan penggunaan sistem "update your chapter", hal ini dikarenakan mereka dapat dengan mudah memberikan dan mendapatkan informasi pembelajaran, membentuk forum diskusi belajar dengan teman-teman mereka sehingga dapat menyelesaikan tugas-tugasnya lebih cepat. Selain itu, ada juga yang beralasan senang dengan adanya penggunaan sistem update your chapter karena bisa mendapatkan contoh jawaban tugas kuliah. Hanya ada 7 responden yang kurang setuju dengan adanya penggunaan sistem update your chapter dengan alasan kurang efektif karena harus menggunakan jaringan internet sehingga menambah biaya pulsa. Selain itu, responden juga berpendapat bahwa Penggunaan situs jejaring sosial sebagai media belajar dengan caraupdate chapter dapat 
meningkatkan motivasi belajar mereka dan dapat membantu mahasiswa memahami materi perkuliahan.

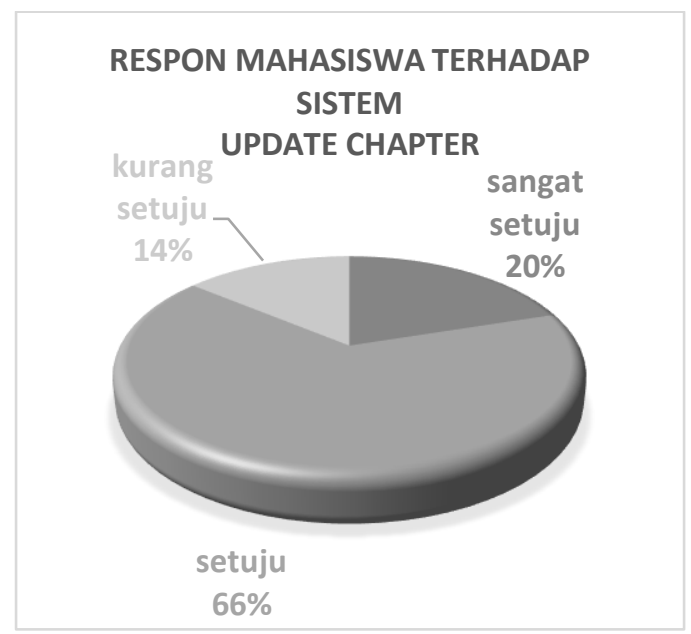

Gambar 4.2 Respon mahasiswa terhadap sistem update chapter

Kegiatan yang sering dilakukan responden saat membuka group update chapter berdasarkan hasil angket kuisioner antara lain; 10 responden menjawab untuk membaca update chapter atau komentar teman-teman mereka, 35 responden menyatakan untuk membaca dan kemudian memberi komentar serta ikut meng-update chapter mereka.Namun masih ada juga 3 responden yang mengaku hanya membuka saja tanpa membaca atau memberi komentar. Penelitian ini juga mengungkapkan bahwa sebagian besar responden selalu membaca buku-buku referensi matakuliah sebelum meng-update chapter atau memberi komentar. Sebanyak 10 responden yang menjawab kadangkadang dan 3 responden menjawab tidak membaca buku referensi sebelum memberi komentar.

\section{SIMPULAN}

Situs jejaring sosial di era disrupsi selain sebagai alat komunikasi juga dapat dimanfaatkan sebagai media pembelajaran yang menarik bagi mahasiswa dengan caraupdate chapter. Sebelumnya situs jejaring sosial hanya banyak digunakan untuk sarana mendapatkan hiburan dan update status atau untuk memperbarui gambar atau mengungkapkan perasaan penggunanya terhadap kondisi sekitar. Maka dengan update chapter mereka telah beralih mengupdate atau memperbarui status mereka dengan memposting teori-teori dari buku literature perkuliahan yang telah dibacanya, sehingga mereka akan termotivasi untuk lebih banyak membaca buku literature perkuliahan.

Respon mahasiswa terhadap pemanfaatan situs jejaring sosial sebagai media pembelajaran sangat positif, karena dengan begitu mereka dapat lebih mudah memberikan dan mendapatkan informasi pembelajaran, membentuk forum diskusi belajar dengan teman-teman mereka sehingga dapat menyelesaikan tugas-tugasnya lebih cepat. Penelitian ini juga mengungkapkan bahwa sebagian besar mahasiswa sangat aktif membuka dan membaca group update chapter mereka setiap saat ada teman yang meng-update chapter atau memberi komentar. Kemudian, mereka juga sering menuliskan update chapter atas apa yang telah mereka baca dan pelajari dari 
buku-buku referensi perkuliahannya. Mereka tidak mau mengupdate chapter asal-asalan tanpa landasan teori karena hal itu akan menjadikan update mereka tidak menarik dan tidak mendapatkan poin nilai tinggi.

\section{DAFTAR PUSTAKA}

Arsyad, A. 2013. Media Pembelajaran. Jakarta: PT Raja Grafindo.

Benthaus, J., Pahlke, I., Beck, R. \& Seebach, C., 2013. Improving Sensing and Seizing Capabilities of a Firm By Measuring Corporate Reputation Based on Social Media Data. Proceedings of the 21st European Conference on Information Systems IMPRO, pp.1-12.

Boyd, D. M. \& Ellison, N. B., 2007. Social Networking Sites: Definition, History, and Scholarship. Journal of Computer-Mediated

Communication, 13(1), pp.210-230.

Daryanto. 2012. Media Pembelajaran. Bandung: Satu Nusa.

Hamzah, Almed.2016. Tingkat Penerimaan Mahasiswa terhadap Penggunaan Situs Jejaring Sosial sebagai Media Pembelajaran. TEKNOMATIKA Vol. 8, No. 2, pp.55-60

Kaplan, A. M. \& Haenlein, M., 2010. Users of the world, unite! The challenges and opportunities of Social Media. Business horizons, 53(1), pp.59-68.

Kirkwood, A. \& Price, L., 2014. Technology-enhanced learning and teaching in higher education: what is 'enhanced'and how do we know? A critical literature.

Nasrullah, R. 2015. Media Sosial: Perspektif Komunikasi, Budaya, dan Sosioteknologi. Bandung: SImbiosa Rekatama Media.

Silius, K., Miilumaki, T., Huhtamaki, J., Tebest, T., Marilainen, J. \& Pohjolainen, S. 2010. Students' motivations for social media enhanced studying and learning. Knowledge Management \& E-Learning: An International Journal (KM\&EL), 2(1), PP.51-67.

Sopiah, N., 2013. Faktor-Faktor yang Mempengaruhi Penggunaan Media Facebook. Proceeding Seminar Nasional Aplikasi Teknologi Informasi (SNATI) 2013, Universitas Islam Indonesia, pp.1620. 